Original Research Paper

\title{
Economic and Financial Flow Generation in Tomato Industry in Italy
}

\author{
Giuseppe Bonazzi and Mattia Iotti \\ Department of Civil Engineering, Environment, \\ Territory and Architecture (DICATeA), University of Parma, Parma, Italy
}

\author{
Article history \\ Received: 14-06-2014 \\ Revised: 20-01-2015 \\ Accepted: 19-02-2015 \\ Corresponding Author: \\ Giuseppe Bonazzi \\ Department of Civil \\ Engineering, Environment, \\ Territory and Architecture \\ (DICATeA), University of \\ Parma, Parma, Italy \\ E-mail: giuseppe.bonazzi@unipr.it
}

\begin{abstract}
In many Italian regions, firms operating in tomato industry have made significant investments in plants and machinery and often sell products to large food retail chains that require large stocks of inventory and have an average time of over 150 days for the payment of receivables. These management characteristics amplify capital requirements, in large part financed, increasing debt levels. Also, because of the increasing costs of raw materials in recent years, many firms in the tomato processing sector in Italy have suffered a corporate crisis and even bankruptcy. Therefore, tomato processing firms need to properly control management, particularly in applying indicators that express the sustainability of the financial cycle. To achieve this goal, the article analyzes the annual account data of a sample of 54 tomato processing firms in Italy across a five-year period, showing that economic margins traditionally applied to assess the sustainability of the management cycle differ significantly from financial margins. Moreover, the annual account data of the sample firms highlight the difficulties in credit access, expressed by applying a multiple regression model to analyze return on equity and flow on equity generation. To deepen the analysis, the considered methods could be applied to other agri-food firms, particularly if characterized by high capital intensity.
\end{abstract}

Keywords: Tomato Processing Firms, Italian Agri-Food Sector, Free Cash Flow to Equity, Flow on Equity

\section{Introduction}

The cultivation and processing of tomatoes characterizes various areas of Italy, a country in which the tomato is one of the most important components of agricultural food production. Tomato processing firms are mostly located in the Emilia-Romagna, Lombardia, Piemonte, Puglia and Campania regions and have characteristics of production and investment that influence capital structure. Processing firms have large amounts of capital in terms of equity capital and/or debt to support investment in fixed assets (buildings, plants and equipment for tomato processing) and working capital (inventories, including finished goods and accounts receivable). In view of the high absorption of capital due to the fixed asset and working capital cycles and due to the high level of debt, it is even necessary to assess the sustainability of the business cycle. Again several studies have shown that in tomato processing sector. Moreover, labor force productivity is a key factor in firms' competition since vegetable agriculture generally is labor intensive; this feature makes the sector of production and processing tomatoes very important in terms of social impact on employment (Keskin et al., 2010) and in terms of contractual relations of supply chain (Engindeniz, 2007). In the transformation sector, these evaluations are particularly important in a situation involving reduction of bank credit; in fact, firms' managers can make erroneous strategic decisions, even risk default for their companies, because of the time lag that exists between the business cycle and financial cycle. In fact, in recent years, the tomato processing firms were characterized by various crisis situations. Since firms in the sector are often Small and Medium Enterprises (SMEs), it is important to identify correct ratios of analysis because SME enterprises have generally limited access to capital markets (stock market, venture capital, private equity) and debt financing (bank loans, structured finance, syndicated loans) as evidenced in several researches (Grablowsky, 1984; Dunn and Cheatham, 1999; Peel and Wilson, 1996; Molina and Preeve, 2009; Bonazzi and Iotti, 2014b). 
Given the difficulties of the firms in the sector, the objective of the article is to analyze the management data of tomato processing firms in Italy, particularly with respect to capital structure, sustainability of the management cycle and credit access. First, the analysis applies to a firm's sample comparison between profit margins and financial margins in order to highlight whether there are statistically significant differences. The data analysis is then developed, applying two multiple regression models to quantify the determinants of the generation of profit and cash flow to equity holders in the tomato processing firms. Data analysis of the sector, particularly within the current situation of economic crisis, aims to provide useful information to a firm's management to evaluate the sustainability of a firm's financial cycle. The results of the article could be applied even by policy makers through public actions to support private firms, including a public line of credit, in order to correctly evaluate the financial viability of firms that have received public funds. It could then be possible to limit the risk of inefficient uses of collective resources. Indeed, the sector of the tomato is the object of several public aids by the European Union (EU), as it plays an important role in the environmental sustainability of the agricultural sector (Di Trapani et al., 2014). In fact, sustainable development is a strategic objective of the EU mainly with regard to mid or long-term development (Battilani, 2007). The analysis of sustainability affects many agricultural productions, just for the role of agriculture in the occupation of the soil. This is especially true in the Mediterranean basin, where the evaluation of profitability often also requires an assessment of environmental sustainability, as evidenced by several studies (Sgroi et al., 2014a; 2014b).

\section{Material and Methods}

The return on equity capital has to be not only positive, in terms of profit and even in terms of intermediate income margins, but also higher than the opportunity cost of capital (Lagerkvist and Andersson, 1996). In order to quantify return on equity capital, it could be possible to apply, jointly or separately, an economic or a financial approach. An economic approach compares revenues and costs, applying the accrual methods, then considering the value creation, as expressed by accounting data, in order to quantify profit and intermediate income margins. A financial approach considers cash inflow and outflow, calculated on a cash basis, to express the cash flow available for a firm's management and available for equity holders to distribute dividends or to perform discretionary investments. Moreover, economic and financial approaches may have different results, as expressed by several researchers (Bowen and Owen, 1986; Dechow, 1994; Iotti and Bonazzi, 2014). Researchers have shown that firms could suffer an unsustainable financial cycle even when income margins are positive. In these cases, firms may be subject to financial un-sustainability of the management cycle as expressed in several studies about the fixed asset cycle (Fazzari and Petersen, 1993; Cleary, 1999; De Miguel and Pindado, 2001) and working capital cycle (Howorth and Westhead, 2003; Padachi, 2006; Taylor, 2011). The differences in each firm's results, applying an economic or a financial approach, could be caused by lags between economic and financial cycles, as several studies have shown (Greenberg et al., 1986; Kwon, 1989; Dechow and Dichev, 2002; Russel, 2009). This situation occurs particularly in firms in which we note high levels of capital absorption as is often the case for agri-food processing firms, even affecting firms' scoring (Glancey, 1998; Kieschnick et al., 2008; Bonazzi and Iotti, 2014a). Information based on a cash flow approach has its practical applications considering the limits of a traditional accounting system, which is based on the principles of historical cost and accrual basis value analysis. The importance of analyzing operating cash flows, in comparison with accounting values, is exposed by several studies that consider a firm's capacity to generate future cash flow in comparison with accrual results as in (Finger, 1994; Wang and Eichenseher, 1998; Charitou and Panagitodes, 1999; Hussain and Al-Attar, 2004). On this topic, we first have to consider that income margins such as Earnings before Interest, Tax, Depreciation and Amortization (EBITDA) and Earnings before Interest and Tax (EBIT), often applied even in cover ratio covenants (Dothan, 2006; Gray et al., 2006) do not directly express the liquidity generated by firm management. Moreover, the public annual account is the main account to which an accrual approach. The annual account includes balance sheet, income statement and integrative note, as expressed by $D$. Lgs. 127/91, which applies to the fourth EU directive about company and annual accounts (EU Directive $78 / 660 /$ EEC IV of July 25, 1978). For a generic firm and for a generic period, $t$, the balance sheet expressing investments and sources of capital could be expressed as follows:

$$
\begin{aligned}
& \mathrm{FA}_{\mathrm{t}}+\mathrm{WCi}_{\mathrm{t}}^{\mathrm{a}}+\mathrm{WCar}_{\mathrm{t}}^{\mathrm{a}}+\mathrm{WCo}_{\mathrm{t}}^{\mathrm{a}}+\mathrm{L}_{\mathrm{t}}= \\
& =\mathrm{E}_{\mathrm{t}}^{\mathrm{sc}}+\mathrm{E}_{\mathrm{t}}^{\mathrm{r}}+\Pi_{\mathrm{t}}^{\mathrm{pT}}+\mathrm{WCap}_{\mathrm{t}}^{\mathrm{p}}+\mathrm{WCo}_{\mathrm{t}}^{\mathrm{p}}+ \\
& +\mathrm{DF}_{\mathrm{t}}^{\mathrm{M}<12}+\mathrm{DF}_{\mathrm{t}}^{\mathrm{M}>12}
\end{aligned}
$$

In Equation 1, investments are represented by Fixed Assets (FA), $\mathrm{WCi}^{\mathrm{a}}$ (working capital asset, inventories), WCara (working capital asset, accounts receivable), $\mathrm{WCo}^{\mathrm{a}}$ (working capital asset, other assets) and $\mathrm{L}$ (liquidity); the sources of capital are represented by $\mathrm{E}^{\mathrm{sc}}$ (share capital), $\mathrm{E}^{\mathrm{r}}$ (reserves), $\Pi^{\mathrm{p}^{\mathrm{T}}}$ (profit after tax), $\mathrm{WCap}^{\mathrm{p}}$ (working capital debt, accounts payable), $\mathrm{WCo}^{\mathrm{p}}$ 
(working capital debt, other values), $\mathrm{DF}^{\mathrm{M}<12}$ (financial debt due within 12 months) and $\mathrm{DF}^{\mathrm{M}>12}$ (financial debt due after 12 months). The first member of (1) for the generic period, $t$, represents the invested capital that is, Total Assets (TA) while the second member represents the total sources of capital as the sum of equity capital $(\mathrm{ET}=$ $\left.\mathrm{E}^{\mathrm{sc}}+\mathrm{E}^{\mathrm{r}}+\Pi^{\mathrm{pT}}\right)$ and debt capital $\left(\mathrm{DT}=\mathrm{WCap}^{\mathrm{p}}+\mathrm{WCo}^{\mathrm{p}}+\right.$ $\mathrm{DF}^{\mathrm{M}<12}+\mathrm{DF}^{\mathrm{M}>12}$. Net position of financial credit and debt for the generic period, $t$, is Net Financial Position $\left(\mathrm{NFP}_{t}\right)$ and could be expressed as follows Equation 2:

$$
\left(\mathrm{DF}_{\mathrm{t}}^{\mathrm{M}<12}+\mathrm{DF}_{\mathrm{t}}^{\mathrm{M}>12}\right)-\mathrm{L}_{\mathrm{t}}=\mathrm{NFP}_{\mathrm{t}}
$$

Net investment in Working Capital $\left(\mathrm{NWC}_{\mathrm{t}}\right)$ expresses the absorption of financial resources as a result of the acquisition, processing and sale cycle as follows:

$$
\begin{aligned}
& \left.\mathrm{WCi}_{\mathrm{t}}^{\mathrm{a}}+\mathrm{WCar}_{\mathrm{t}}^{\mathrm{a}}+\mathrm{WCo}_{\mathrm{t}}^{\mathrm{a}}\right)-\left(\mathrm{WCap}_{\mathrm{t}}^{\mathrm{p}}+\mathrm{WCo}_{\mathrm{t}}^{\mathrm{p}}\right)= \\
& =\mathrm{WC}_{\mathrm{t}}^{\mathrm{aT}}-\mathrm{WC}_{\mathrm{t}}^{\mathrm{pT}}=\mathrm{NWC}_{\mathrm{t}}
\end{aligned}
$$

In Equation 3, given the generic period, $\mathrm{t}, \mathrm{WC}^{\mathrm{aT}}$ is the working capital total asset and $\mathrm{WC}^{\mathrm{pT}}$ is working capital total debt; NWC quantifies the net resources generated $\left(\mathrm{NWC}_{\mathrm{t}}<0\right)$ or absorbed $\left(\mathrm{NWC}_{\mathrm{t}}>0\right)$ by the working capital management cycle (Lorek and Willinger, 1996). For a generic company, given a generic period, t, we have to consider that an income statement quantifies the accounting profit generated in favor of the equity holders. First, we have to quantify the Value of Production (VP) for a generic period, $t$, as follows:

$$
\begin{aligned}
& \sum_{\mathrm{i}=1}^{\mathrm{I}} \mathrm{p}_{\mathrm{t}, \mathrm{i}} \mathrm{q}_{\mathrm{t}, \mathrm{i}}+\left(\sum_{\mathrm{f}=1}^{\mathrm{F}} \mathrm{I}_{\mathrm{t}, \mathrm{f}} \mathrm{V}_{\mathrm{t}, \mathrm{f}}-\sum_{\mathrm{g}=1}^{\mathrm{G}} \mathrm{I}_{\mathrm{t}-1, \mathrm{~g}} \mathrm{v}_{\mathrm{t}-1, \mathrm{~g}}\right)= \\
& =\mathrm{S}_{\mathrm{t}}+\left(\mathrm{I}_{\mathrm{t}}-\mathrm{I}_{\mathrm{t}-1}\right)=\mathrm{S}_{\mathrm{t}}+\Delta \mathrm{I}_{\mathrm{t}, \mathrm{t}-1}=\mathrm{VP}_{\mathrm{t}}
\end{aligned}
$$

In Equation 4, $\mathrm{p}_{\mathrm{t}, \mathrm{i}}$ is price per unit, at a certain time, $\mathrm{t}$, of goods and services sold as part of $I$ : $I \geq 1, q_{t}$ is quantity sold and $I_{t, f}$ and $I_{t-1, f}$ are inventories part of $F: F \geq 1$ and $\mathrm{G}: \mathrm{G} \geq 1$, respectively, at a certain time, $t$ and $t-1$. These goods are valued at their respective value per unit, which is $\mathrm{v} ; \mathrm{S}_{\mathrm{t}}$ is total sales at a certain time, $\mathrm{t}$, then $\Delta \mathrm{I}_{\mathrm{t}, \mathrm{t}-1}$ expresses the variation in inventory values between $\mathrm{t}-1$ and $t$. The Value of Production (VP) is a flow value, namely a value that is in formation during a period in this case $(\mathrm{t})$ without considering value assumed during the period $T \in[t-1, t]$. Operative costs for a given time, $t$, are as follows:

$$
\begin{aligned}
& \mathrm{M}_{\mathrm{t}}=\sum_{\mathrm{m}=1}^{\mathrm{M}} \mathrm{m}_{\mathrm{t}, \mathrm{m}} \mathrm{q}_{\mathrm{t}, \mathrm{m}} ; \mathrm{S}_{\mathrm{t}}=\sum_{\mathrm{s}=1}^{\mathrm{S}} \mathrm{s}_{\mathrm{t}, \mathrm{s}} \mathrm{q}_{\mathrm{t}, \mathrm{s}} ; \mathrm{R}_{\mathrm{t}}= \\
& =\sum_{\mathrm{r}=1}^{\mathrm{R}} \mathrm{r}_{\mathrm{t}, \mathrm{r}} \mathrm{q}_{\mathrm{t}, \mathrm{r}} ; \mathrm{L}_{\mathrm{t}}=\sum_{\mathrm{l}=1}^{\mathrm{L}} \mathrm{1}_{\mathrm{t}, 1} \mathrm{q}_{\mathrm{t}, \mathrm{l}} ; \mathrm{O}_{\mathrm{t}}=\sum_{\mathrm{o}=1}^{\mathrm{O}} \mathrm{o}_{\mathrm{t}, \mathrm{o}} \mathrm{q}_{\mathrm{t}, \mathrm{o}}
\end{aligned}
$$

$M_{t}$ represents the cost of raw materials, $S_{t}$ the cost of services, $R_{t}$ the cost of rent and leasing, $L_{t}$ the labor cost and $\mathrm{O}_{\mathrm{t}}$ other operative costs. In Equation $5, \mathrm{~m}_{\mathrm{t}, \mathrm{m}}, \mathrm{s}_{\mathrm{t}, \mathrm{s}}, \mathrm{r}_{\mathrm{t}, \mathrm{r}}$, $1_{t, 1}$ and $o_{t, o}$ express, for a given time, $t$, the single factors of costs, so we have $\mathrm{M}: \mathrm{M} \geq 1, \mathrm{~S}: \mathrm{S} \geq 1, \mathrm{R}: \mathrm{R} \geq 1, \mathrm{~L}: \mathrm{L} \geq 1$ and $\mathrm{O}: \mathrm{O} \geq 1$ with their respective quantities, $\mathrm{q}_{\mathrm{t}, \mathrm{m}}, \mathrm{q}_{\mathrm{t}, \mathrm{s}}, \mathrm{q}_{\mathrm{t}, \mathrm{r}}$, $q_{t, 1}$ and $q_{t, o}$. The operative costs without financial effect are as follows Equation 6:

$D_{t}=\sum_{d=1}^{D} d_{t, d} q_{t, d} ; A_{t}=\sum_{a=1}^{A} a_{t, a} q_{t, a}$

$D_{t}$ represents amortizations of Fixed Assets $\left(F A_{t}\right)$, while $A_{t}$ represents depreciation. In (6), $d_{t, d}$ and $a_{t, a}$ are the costs per unit, at a certain time $(\mathrm{t})$ of amortizations and depreciation; these costs are, respectively, part of $D: D \geq 1$ and $A: A \geq 1$. The respective quantities are $q_{t, d}$ and $\mathrm{q}_{\mathrm{t}, \mathrm{a}}$. The balance of the financial operation ( $\mathrm{SFt}$ ), at $\mathrm{t}$, is as follows:

$\mathrm{SF}_{\mathrm{t}}=\mathrm{I}_{\mathrm{t}}^{\mathrm{a}}-\mathrm{I}_{\mathrm{t}}^{\mathrm{p}}$

In Equation 7, $\mathrm{I}^{\mathrm{a}}$ represents interest receivable at a certain time $(\mathrm{t}), \mathrm{I}^{\mathrm{p}}$ while represents interest payable at a certain time $(\mathrm{t})$. The balance of the extraordinary operations $\left(\mathrm{SX}_{\mathrm{t}}\right)$ is as follows:

$S X_{t}=X_{t}^{a}-X_{t}^{p}$

In Equation 8, $\mathrm{X}^{\mathrm{a}}$ represents extraordinary income and $\mathrm{X}^{\mathrm{p}}$ represents extraordinary expense. The balance of the management revaluations and devaluations of financial assets is given as follows:

$S Z_{t}=Z_{t}^{a}-Z_{t}^{p}$

In Equation 9, $Z^{\mathrm{a}}$ represents revaluations of financial activities, while $Z^{\mathrm{p}}$ represents devaluations of financial activities. Hence it is as follows:

$$
\begin{aligned}
& \mathrm{VP}_{\mathrm{t}}-\left(\mathrm{M}_{\mathrm{t}}+\mathrm{S}_{\mathrm{t}}+\mathrm{R}_{\mathrm{t}}+\mathrm{L}_{\mathrm{t}}+\mathrm{O}_{\mathrm{t}}\right)=\mathrm{EBITDA}_{\mathrm{t}} \\
& \mathrm{EBITDA}_{\mathrm{t}}-\left(\mathrm{D}_{\mathrm{t}}+\mathrm{A}_{\mathrm{t}}\right)=\mathrm{EBIT}_{\mathrm{t}} \\
& \mathrm{EBIT}_{\mathrm{t}}+\mathrm{SF}_{\mathrm{t}}+\mathrm{SX}_{\mathrm{t}}+\mathrm{SZ}_{\mathrm{t}}=\Pi_{\mathrm{t}}^{\mathrm{aT}}
\end{aligned}
$$

In Equation 10, EBITDA approximates the creation of liquidity, net of nonmonetary costs $\left(D_{t}+A_{t}\right)$, while it does not have this capacity for the value of production, considering monetary $\left(\mathrm{S}_{\mathrm{t}}\right)$ and nonmonetary values $\left(\Delta \mathrm{I}_{\mathrm{t}, \mathrm{t}-1}\right)$; EBIT is an income margin that expresses operative income; $\Pi^{\mathrm{aT}}$ is profit before taxes and profit after taxes is given $\left(\prod^{\mathrm{pT}}\right)$ as follows:

$\Pi_{t}^{\mathrm{aT}}-\mathrm{T}_{\mathrm{t}}^{\mathrm{Y}}=\Pi_{\mathrm{t}}^{\mathrm{pT}}$

In Equation 11, $\Pi^{\mathrm{p}^{\mathrm{T}}}$ (PROFIT) expresses the firm's capacity to remunerate, at $t$, the equity capital; $\mathrm{T}^{\mathrm{Y}}$ 
represents income taxes. We can then express an income statement as follows Equation 12:

$$
\begin{aligned}
& \mathrm{VP}_{\mathrm{t}}-\left(\mathrm{M}_{\mathrm{t}}+\mathrm{S}_{\mathrm{t}}+\mathrm{R}_{\mathrm{t}}+\mathrm{L}_{\mathrm{t}}+\mathrm{O}_{\mathrm{t}}\right)=\text { EBITDA }_{\mathrm{t}} \\
& \mathrm{EBITDA}_{\mathrm{t}}-\left(\mathrm{D}_{\mathrm{t}}+\mathrm{A}_{\mathrm{t}}\right)=\mathrm{EBIT}_{\mathrm{t}} \\
& \mathrm{EBIT}_{\mathrm{t}}+\mathrm{SF}_{\mathrm{t}}+\mathrm{R}_{\mathrm{t}}+\mathrm{X}_{\mathrm{t}}-\mathrm{T}_{\mathrm{t}}=\Pi_{\mathrm{t}}^{\mathrm{pT}}(\text { PROFIT })
\end{aligned}
$$

An income statement is not suitable for financial analysis and for quantifying cash flow; to achieve this goal, it is necessary to predispose financial statements. In terms of the definition of 'cash flow', there was a change in researchers' approaches during times. The first definition considers cash flow as the sum of an accounting result (profit or EBIT) plus depreciation and amortizations (Beaver, 1966); other researchers (Gombola et al., 1987) began to express cash flow while taking into account the absorption or generation of cash via the working capital cycle and this approach was considered in several studies (Rayburn 1986; Wilson, 1987; Finger, 1994; Lorek and Willinger, 1996):

$$
\begin{aligned}
& \Pi_{t}^{\mathrm{pT}}+\left(D_{t}+A_{t}\right)+S_{t}=C F_{t} ; \\
& C_{t}-\left(N W C_{t}-N W C_{t-1}\right)=O C F_{t} ; \\
& O C F_{t}-\left[\left(F_{t}-F_{t-1}\right)-\left(D_{t}+A_{t}\right)\right]=U F C F_{t} ; \\
& U F C F_{t}-S F=F C F E_{t}
\end{aligned}
$$

In Equation 13, at $\mathrm{t}, \mathrm{CF}_{\mathrm{t}}$ is cash flow, $\mathrm{OCF}_{\mathrm{t}}$ is operating cash flow, $\mathrm{UFCF}_{\mathrm{t}}$ is unlevered free cash flow, $\mathrm{FCFE}_{t}$ is free cash flow to equity and $\mathrm{NWC}_{t}$ is net working capital. Management of working capital is very important, especially for SMEs. These companies have, in fact, limited access to the capital market in the medium and long terms and often finance fixed assets with short-term liabilities (due within 12 months) and partly as a result of these choices for financing, SMEs have rates of default higher than companies of larger sizes. For the most part, tomato processing firms are, in fact, SMEs. In this way, firms with positive profits, due to increased value of their inventories, record a reduction of operating cash equal in absolute value, but of the opposite sign. Given OCFt, liquidity absorption due fixed asset investment has an effect on UFCFt, given that $\left[\left(\mathrm{FA}_{\mathrm{t}}-\mathrm{FA}_{\mathrm{t}-1}\right)-\left(\mathrm{D}_{\mathrm{t}}+\mathrm{A}_{\mathrm{t}}\right)\right]>0 \Rightarrow \Delta \mathrm{UFCF}_{\mathrm{t}, \mathrm{t}-1}$ and vice versa. $U_{F C F}$ is therefore the cash flow available, given the investments in fixed assets, at time $(\mathrm{t})$, to remunerate financial debt and equity capital. This is done through the payment of interest expenses on financial debt $\left(\mathrm{I}^{\mathrm{p}}\right)$ and the distribution of profits to holders of equity capital. In a given period $(t), \mathrm{FCFE}_{t}$ represents the cash flow available for the distribution of dividends to equity holders and for discretionary and nondiscretionary financial debt reduction. In the article, the aim is to assess whether there are statistically significant differences in the economic and financial results of firms in the sample; these results are expressed in terms of economic margins EBITDA, EBIT and $\prod^{\mathrm{p}^{\mathrm{T}}}$ (profit) and in terms of financial results as Cash Flow (CF), operating Cash Flow (OCF), Unlevered Free Cash Flow (UFCF) and Free Cash Flow to Equity (FCFE). To assess the sustainability of the business cycle, applying intermediate profit margins such as EBITDA and EBIT (margins that approximate cash flow values) is necessary considering that these margins do not consider the effect of revenue not collected from customers, purchases not paid to suppliers and changes in the values of stocks (inventories). Profit calculated with an economic approach may differ from the cash flow available for distribution to shareholders (FCFE) in consideration of the time lag between economic value creation and time of occurrence of financial cash flows. It is therefore appropriate to compare income and financial margins to verify the significance of any differences. The main measure of profitability ratios is highlighted by the performance of equity capital:

$\mathrm{ROE}_{\mathrm{t}}=\Pi_{\mathrm{t}}^{\mathrm{pT}} /\left(\mathrm{E}_{\mathrm{t}}^{\mathrm{c}}+\mathrm{E}_{\mathrm{t}}^{\mathrm{s}}+\Pi_{\mathrm{t}}^{\mathrm{pT}}\right)$

In Equation 14, Return on Equity (ROE) expresses the economic annual return of equity capital (Ohlson, 1980; Barnes, 1987). This ratio measures profitability but is affected by accounting conventions that are the basis of the calculation of profit. It is therefore possible to have a situation in which equity holders, even in the presence of positive profit, are not able to distribute dividends. To overcome this problem, the work also proposes the application of the following:

$\mathrm{FOE}_{\mathrm{t}}=\mathrm{FCFE}_{\mathrm{t}} /\left(\mathrm{E}_{\mathrm{t}}^{\mathrm{c}}+\mathrm{E}_{\mathrm{t}}^{\mathrm{s}}+\Pi_{\mathrm{t}}^{\mathrm{pT}}\right)$

In Equation 15, Flow on Equity (FOE) expresses the annual financial performance of equity capital as already indicated by (Bodenhorn, 1964; Moro Visconti, 1999). In the article, we compare $\mathrm{ROE}_{\mathrm{t}}$ and $\mathrm{FOE}_{\mathrm{t}}$ values to quantify the correlation and difference between these ratios. We even apply two linear regression models to assess which are the explanatory variables of $\mathrm{ROE}_{\mathrm{t}}$ and $\mathrm{FOE}_{\mathrm{t}}$ in the tomato sector firms considered in the sample.

\section{Results}

The cultivation and processing of tomatoes characterizes various areas of Italy, a country in which the tomato is one of the most important components of agricultural food production. In recent years, the national tomato sector has been subject to profound changes, even considering that several emerging producer countries, including China, have increased their production with important changes in international trade dynamics, in quantitative and even qualitative terms.

In recent years, the land surface for tomato production in Italy has been decreasing $-11.80 \%$ for the 
period 2008-2012; this contraction is greater for tomatoes for food consumption $(-17.06 \%)$ compared to tomatoes for the processing industry $(-10.49 \%)$. The production of tomatoes for food processing increased in the same period $(0.93 \%$ in production and $1.33 \%$ in harvesting), with an increase in average yields per hectare, while the production of tomatoes for food consumption decreased by $16.06 \%$ in production and $16.75 \%$ in harvesting. The transformation of the tomato has taken place generally in plants adjacent to the areas of production because of specific strategic purposes, particularly those related to cost reduction. The reduction in transportation costs to get the raw materials from production areas to processing plants has, in fact, been a great part of this concentration process for productions plants. In Italy, the concentration of the tomato production industry is particularly high in two main geographical areas.

The most important production area for tomatoes is located in the northern part of Italy, including the regions of Emilia-Romagna, Lombardia, Veneto and Piemonte, which produced 2.4 million tons in 2012 (45\% of domestic tomato production). The second area is located in the southern regions of Campania, Puglia, Calabria and Basilicata, which produced 2.3 million tons in 2012 (43\% of national production). In southern Italy, 96 tomato processing firms were operating in 2012, of which 79 are limited companies, 12 are nonlimited companies and sole proprietorships and 5 are cooperative firms. In northern Italy (Emilia-Romagna, Lombardia, Veneto and Piemonte regions), the tradition of processing tomatoes has its origins in the late 19th century with the rise of the canning industry in the province of Parma. This type of industrial process still characterizes the territories of the provinces of Parma and Piacenza, in the Emilia-Romagna region, with the presence of processing firms also in Modena Province and in some other provinces of eastern Emilia-Romagna on the right side of the river Po and even in the lower areas of Lombardia (Cremona and Lodi Provinces), in the Veneto region and in Alessandria Province (Piemonte region). In these territories, 25 processing firms are active, of which 18 are limited companies, 6 are cooperatives and 1 is a nonlimited company. Among the three major production regions of northern Italy, Emilia-Romagna prevails, with 16 processing firms. Some companies only carry out the production of tomatoes, with the concentration of production only in summer, using seasonal labor during the peak of production and having maintenance activities, storage activities and marketing activities for the rest of the year. In other cases, companies cover production that includes several canned vegetables and juices in order to reduce the seasonality of tomato production. The distribution of the processed tomato is in large part through the channel of large supermarket chains; these retailers use their bargaining power to impose low trading prices of the finished product on the processing industry, even applying unfavorable conditions to dilate the average time for payment of suppliers (i.e., processing firms).

Processing firms even suffer from the transformation of production that is frequently not differentiable and even with modest brand recognition among consumers, having that low level of consumer loyalty reduces the bargaining power of processing firms in the face of distribution firms. Tomato processing firms often have difficulty relating to the duration of the financial cycle since they require high investments in fixed assets such as real estate and buildings, plants and equipment for production and storage of products. Moreover, in the sector, the working capital cycle determines an expansion of investment, even considering that sales to large food distribution chains lead to a time dilation in collecting receivables with negative effects on the financial sustainability of the business cycle. Since the change in inventories and sales not yet received has a positive impact on production value and profit, it is possible to note a misalignment between profit and cash flow for tomato processing firms in situations wherein companies, even if characterized by positive profit, are not able to sustain the payments of the financial cycle. In recent years, the processing firms of the sector have been characterized, because of this market scenario, by a large number of corporate crises, which have also led to bankruptcy and liquidation. In Italy, there has been a decrease in the number of firms in the last decade, from 172 firms in 2008 to 158 firms in 2012, with the closure of 24 firms, of which 7 are bankruptcies or compulsory liquidations.

The data considered in the analysis were made available by the registrar of companies database considering 2007 as the base year; the data extraction covers the five-year period from 2008 to 2012 and uses the annual accounts filed by limited companies and cooperatives each year at the registrar of companies. In the analysis, a total of 270 years of firm data have been considered. Data analysis was performed using the statistical package SPSS, issue 19.

The analysis of the sample firms first considers asset data 2008/2012 (Table 1) of the annual balance sheet; these data have interest because they express the high level of capital intensity required for the tomato processing activities of the firms in the sample, given the value of production (TA/VP mean is $161.94 \%$ ). Sector firms are capital-intensive, considering fixed assets and the working capital cycle. The mean data show the importance of investments in fixed assets (FA: $34.60 \%$ of TA) and in the inventories of working capital (WCia: $43.56 \%$ of TA). Tomato processing firms, in fact, require investments in land and buildings even to store finished products and in plants and machinery to process raw materials. 
Table 1. Balance sheet data of tomato processing sample firms (2008/2012) reclassification of the balance sheet with financial approach

\begin{tabular}{lllllrr}
\hline Values & Mean values $(€)$ & Mean values $(\%)$ & Median Values $(€)$ & Standard Dev. & Skewness & Kurtosis \\
\hline FA & $7,190,295$ & 34.60 & $2,622,949$ & $9,987,971$ & 1.53 & 0.71 \\
WCi $^{\mathrm{a}}$ & $9,051,939$ & 43.56 & $6,132,175$ & $10,465,119$ & 2.68 & 6.86 \\
$\mathrm{WCar}^{\mathrm{a}}$ & $3,602,675$ & 17.34 & $2,865,639$ & $2,928,818$ & 1.05 & -0.15 \\
$\mathrm{WCo}^{\mathrm{a}}$ & 643,849 & 3.10 & 682,730 & 430,440 & -0.13 & -1.31 \\
$\mathrm{WC}^{\mathrm{aT}}$ & $13,298,463$ & 63.99 & $8,942,432$ & $13,114,386$ & 2.29 & 4.87 \\
$\mathrm{~L}$ & 293,162 & 1.41 & 133,547 & 282,640 & 1.28 & 0.84 \\
TA & $20,781,920$ & 100.00 & $13,108,774$ & $22,399,365$ & 1.80 & 2.08 \\
$\mathrm{E}^{\mathrm{T}}$ & $2,428,674$ & 11.69 & 987,304 & $3,185,645$ & 1.85 & 2.17 \\
$\mathrm{WCap}^{\mathrm{s}}$ & $3,993,015$ & 19.21 & $3,464,949$ & $3,366,810$ & 1.82 & 2.63 \\
$\mathrm{WCo}^{\mathrm{s}}$ & $2,311,487$ & 11.12 & $1,025,205$ & $3,251,422$ & 2.10 & 3.34 \\
$\mathrm{WC}^{\mathrm{s}}$ & $6,304,501$ & 30.34 & $4,217,529$ & $6,524,341$ & 2.01 & 2.95 \\
$\mathrm{DF}^{\mathrm{M}<12}$ & $8,922,267$ & 42.93 & $5,231,765$ & $9,238,826$ & 1.89 & 3.06 \\
$\mathrm{DF}^{\mathrm{M}>12}$ & $3,126,478$ & 15.04 & $1,107,844$ & $4,838,589$ & 1.74 & 1.47 \\
$\mathrm{DF}^{\mathrm{T}}$ & $12,048,745$ & 57.98 & $5,689,906$ & $13,923,189$ & 1.85 & 2.51 \\
$\mathrm{D}^{\mathrm{T}}$ & $18,353,246$ & 88.31 & $12,075,041$ & $19,876,450$ & 1.99 & 2.98 \\
TS & $20,781,920$ & 100.00 & $13,108,774$ & $22,399,365$ & 1.80 & 2.08 \\
\hline Source & Or & & & &
\end{tabular}

Source: Our processing of directly collected data

Table 2. Income statement data of tomato processing sample firms (2008/2012) reclassification of the income statement with value added approach

\begin{tabular}{llllllc}
\hline Values & Mean values $(€)$ & Mean values $(\%)$ & Median Values $(€)$ & Standard Dev. & Skewness & Kurtosis \\
\hline VP & $12,832,821$ & 100.00 & $11,004,370$ & $9,314,738$ & 1.16 & 0.74 \\
M & $-6,869,041$ & 53.53 & $-5,910,403$ & $5,061,278$ & 1.25 & 1.20 \\
S & $-2,435,151$ & 18.98 & $-2,044,763$ & $1,850,509$ & 1.42 & 1.83 \\
R & $-333,619$ & 2.60 & $-237,877$ & 358,896 & 1.90 & 3.55 \\
L & $-1,443,586$ & 11.25 & $-1,131,141$ & $1,148,700$ & 1.47 & 2.00 \\
O & $-397,795$ & 3.10 & $-343,780$ & 342,329 & 1.60 & 3.09 \\
EBITDA & $1,353,629$ & 10.55 & $1,075,284$ & $1,335,660$ & 1.46 & 2.60 \\
D & $-394,155$ & 3.07 & $-267,934$ & 416,189 & 2.01 & 4.68 \\
A & $-123,099$ & 0.96 & $-87,599$ & 122,215 & 1.59 & 2.39 \\
EBIT & 836,375 & 6.52 & 610,655 & $1,168,159$ & 1.01 & 2.79 \\
SF & $-452,236$ & -3.52 & $-300,075$ & 506,536 & -1.83 & 3.27 \\
R & 2,591 & 0.02 & 210 & 61,243 & 0.49 & 2.96 \\
X & $-8,940$ & -0.07 & -373 & 129,400 & -0.26 & 4.53 \\
$\Pi^{\text {aT }}$ & 377,790 & 2.94 & 201,890 & $1,130,319$ & 0.21 & 5.66 \\
T & $-199,791$ & 1.56 & $-120,156$ & 383,267 & 0.78 & 4.76 \\
$\Pi^{\text {pT (PROFIT) }}$ & 177,999 & 1.39 & 104,073 & 758,918 & -0.39 & 6.07 \\
\hline
\end{tabular}

Source: Our processing of directly collected data

For the sector, a particularly important investment is in plants, characterized by high technological level (e.g., lines of sterilization and lines of packaging for high productivity) with the relevant cost per unit. These characteristics have the effect of increasing the capital needs to finance investments in improving the firm's efficiency. Accounts receivable $\left(\mathrm{WCar}^{\mathrm{a}}\right)$ are also one of the major factors of asset investment $(25.56 \%$ of TA); the high capital absorption due to this factor of asset investment is determined by large retail chains, whose bargaining power causes an increase in the average number of days for credit payments (accounts receivable). To cover their financial needs, the firms in the sample use financial debts as the first source of capital, given the fact that $\mathrm{DF}^{\mathrm{M}<12}+\mathrm{DF}^{\mathrm{M}>12}$ is $57.98 \%$ of the TA, with a prevalence of loans maturing within 12 months $(42.93 \%$ of the TA) compared with loans maturing after 12 months (15.04\%). The high level of financial debt increases financial dependence on the credit system, even increasing borrowing costs. Equity capital $\left(\mathrm{E}^{\mathrm{T}}\right)$ is, in fact, only $11.69 \%$ of the TA and it is lower than $\mathrm{WC}^{\mathrm{sT}}$, which is equal to $30.34 \%$. The analyzed capital structure shows that firms in the sector acquire a high debt level to finance investment given the fact that equity capital is the third source of capital. This characteristic of the balance sheet of the sample firms expresses the high level of capital absorption in the cycle of working capital; in fact, the mean length of time to collect commercial credit as an account receivable (AR_DAYS) is 108.68 days (median value is 106.66), the mean length of time to pay commercial debt as an account payable (AP_DAYS) is 163.01 days (median value is 161.51) and the mean length of time for inventory stock (INV_DAYS) is 256.90 days (median 
value is 201.97). The average length of the business cycle (inventories plus accounts receivable less accounts payable) is 202.56 days (median value is 147.12). The analysis of the balance sheet in the functional form, then, confirms the dependence of tomato processing firms on financial debt and, consequently, the need for these companies to assess the sustainability of debt services. Further information on the typical characteristics of the firms in the sector results from the analysis of economic data (Table 2); the average value of VP amounts to $€ 12,832,821$ and the largest factor of cost is raw materials $(53.53 \%$ of VP). The cost of services is $18.98 \%$ of VP, while labor costs are the third-largest cost, with an incidence that is $11.25 \%$ of VP; EBITDA and EBIT are, respectively, $10.55 \%$ and $6.56 \%$ of VP. The balance of financial operation (SF) absorbs $3.52 \%$ of VP (i.e., $54.07 \%$ of EBIT). It thus appears that a relevant part of the intermediate profit margins (EBITDA and EBIT) is absorbed by the cost of bank charges due to the financial debt. The income statement data confirm the high impact of interest charges on the results of the firms in the sample. Net profit $\left(\prod^{\mathrm{pT}^{\mathrm{T}}}\right)$ is $€ 177,991$ on average, equal to $1.39 \%$ of the VP value in the sample.

Sample data permit the calculation of a financial statement (Table 3 ) that expresses cash flow availability due to the management cycle. The values of the financial statements of the companies thus calculated show an average CF that is $7.72 \%$ of VP; the average absorption of capital due to the cycle of working capital amounted to $€ 2,279,274$ (i.e., $3.19 \%$ of VP), from which it follows that the average OCF is $€ 3,238,135$ ( $4.35 \%$ of VP). It is then possible to note an important absorption of liquidity because of investments in fixed assets, given that an increase in FA determines a negative UFCF for $1.49 \%$ of $\mathrm{VP}$, with absorption of cash equal to $6.02 \%$ of VP. This means that, on average, considered firms are not able to cover the cost of debt without an increase of equity capital and/or increase in the level of financial debt; this necessity of coverage expresses a financial situation where, on average, FCFE $<0$, implying the impossibility of dividend distribution, if any and/or NFP reimbursement. The analysis of financial statements highlights some typical management characteristics of firms in the tomato food processing sector: (a) The Dynamics of Working Capital (NWC) absorb a significant amount of liquidity generated by operations (CF) as expressed by OCF values, (b) the investments in fixed assets further reduce financial margins available and (c) the balance of financial operations erodes UFCF completely given that FCFE mean and median values are negative.

Descriptive statistics show that intermediate income margins (EBITDA and EBIT) have average values that are higher than financial margins (OCF and UFCF) and also, the median values of income margins are higher than financial margins. EBITDA is positive in 259 cases,
EBIT is positive in 225 cases and CF is positive in 262, while OCF is positive in 201 cases and UFCF only in 159 cases. $\Pi^{\mathrm{pT}^{\mathrm{T}}}$ (PROFIT) also has a value higher than FCFE; PROFIT is positive in 160 cases out of 270 , while FCFE is positive only in 95 cases out of 270 . The analysis thus shows that the application of intermediate margins (EBITDA) could super evaluate the financial results available for the company (UFCF and OCF), expressing that the difference between the income and financial cycles is significant. In particular, the investment cycle, as expressed by UFCF, absorbs a substantial amount of the liquidity of the sample firms as it is expressed by the median values of CF $(€ 900,921)$, OCF $(€ 687,287)$ and UFCF $(€ 338,117)$, while EBITDA $(€ 1,075,284)$ and EBIT $(€ 610,655)$ have higher positive median values. The analysis of the results available for firms in the sample shows a shift between the income cycle and financial cycle. In fact, the median value of PROFIT is $€ 104,073$, while the median value of FCFE is $-€ 17,733$. The analysis of profit then leads to a distorted assessment of the financial situation of the company and also the investments made by the shareholders and although there is accounting remuneration, they are unable to generate available cash flows. In order to analyze the relation between analyzed values, we first verify the normality of the distribution of the income and financial margins applying the Kolmogorov-Smirnov D statistic, given the evidence of the non-normality of distributions for all considered ratios. The KolmogorovSmirnov D statistic (KSD) shows that all values do not follow the normal distribution. The correlation calculated with the parametric approach, using the Pearson statistic (Table 4), shows significant correlations between income margins and financial margins, with high significance $(1.00 \%)$. Moreover, the correlations between FCFE and other margins are not statistically significant, particularly for EBITDA, EBIT and CF between financial margins. Given the reduced sample size and considering the results of the KSD statistic, we also apply a nonparametric approach to correlation (Spearman's $\rho$ ) that confirms the conclusions of the parametric correlation, decreasing, however, the significance of some correlations. The comparisons between income margins and financial margins are performed, evaluating the significance of the difference between means (Table 5 ), calculating Student's t value for paired samples. The analysis considers seven comparisons, including three with EBITDA and financial margins, three with EBIT and financial margins and one between PROFIT and FCFE. The pairwise comparisons with a parametric approach show, without exception, that in all comparisons, we can reject the null hypothesis of equality between means with a two-sided test with significance at $1.00 \%$. 
Giuseppe Bonazzi and Mattia Iotti / American Journal of Applied Sciences 2015, 12 (2): 99.111 DOI: 10.3844/ajassp.2015.99.111

Table 3. Financial statement of the tomato processing sample firms (2008/2012)

\begin{tabular}{|c|c|c|c|c|c|c|}
\hline Values & Mean values $(€)$ & Mean values $(\%)$ & Median Values $(€)$ & Standard Dev. & Skewness & Kurtosis \\
\hline$\prod^{\mathrm{pT} \text { (PROFIT) }}$ & 177,999 & 100.00 & 104,073 & 758,918 & -0.99 & 6.07 \\
\hline$+\mathrm{D}$ & 394,155 & 221.44 & 267,934 & 416,189 & 2.01 & 4.68 \\
\hline$+\mathrm{A}$ & 123,099 & 69.16 & 87,599 & 122,215 & 1.59 & 2.39 \\
\hline$+\mathrm{SF}$ & 452,236 & 254.07 & $-300,075$ & 506,536 & -1.83 & 3.27 \\
\hline $\mathrm{CF}$ & $1,147,489$ & 644.66 & 900,921 & $1,445,925$ & 0.50 & 4.21 \\
\hline$-/+\Delta \mathrm{WCi}^{\mathrm{a}}$ & $-108,105$ & -60.73 & $-86,169$ & 132,569 & -0.72 & 2.43 \\
\hline$-/+\Delta \mathrm{WCar}^{\mathrm{a}}$ & $-94,764$ & -53.24 & $-134,566$ & 678,025 & -1.31 & 12.08 \\
\hline$-/+\Delta \mathrm{WCo}^{\mathrm{a}}$ & $-4,295$ & -2.41 & 36 & 79,220 & -6.75 & 74.53 \\
\hline$\Delta \mathrm{WC}^{\mathrm{aT}}$ & $-207,164$ & -116.38 & $-220,699$ & 668,432 & -1.34 & 11.80 \\
\hline$+/-\Delta \mathrm{WCap}^{\mathrm{s}}$ & $-11,178$ & -6.28 & - & 154,388 & -0.97 & 4.34 \\
\hline$+/-\Delta \mathrm{WCo}^{\mathrm{s}}$ & 13,604 & 7.64 & 1,621 & 111,214 & 0.58 & 8.20 \\
\hline$\Delta \mathrm{WC}^{\mathrm{sT}}$ & 2,426 & 1.36 & 7,065 & 182,409 & -0.62 & 7.73 \\
\hline$\Delta \mathrm{NWC}$ & $-204,738$ & -115.02 & $-213,634$ & 620,354 & -1.12 & 10.32 \\
\hline $\mathrm{OCF}$ & 942,751 & 529.64 & 687,287 & $1,164,869$ & 0.43 & 4.97 \\
\hline$-/+\Delta \mathrm{FA}$ & $-512,619$ & -287.99 & $-349,169$ & 653,094 & -2.13 & 6.59 \\
\hline UFCF & 430,132 & 241.65 & 338,117 & 953,359 & -1.55 & 6.46 \\
\hline - SF & $-452,236$ & -254.07 & $-355,850$ & 506,536 & -1.83 & 3.27 \\
\hline FCFE & $-22,104$ & -12.42 & $-17,733$ & 926,976 & -1.71 & 5.00 \\
\hline
\end{tabular}

Source: Our processing of directly collected data

Table 4. Correlation income and financial margins-parametric approach (Corr. Pearson)

\begin{tabular}{|c|c|c|c|c|c|c|c|c|}
\hline & & EBITDA & EBIT & PROFIT & $\mathrm{CF}$ & OCF & UFCF & FCFE \\
\hline \multirow[t]{3}{*}{ EBITDA } & Corr. Pearson & 1 & $0.933^{*}$ & $0.685^{*}$ & $0.973^{*+}$ & $0.830^{*}$ & $0.759^{* 4}$ & 0.250 \\
\hline & Sig. (2-tailed) & & 0.000 & 0.000 & 0.000 & 0.000 & 0.000 & 0.165 \\
\hline & $\mathrm{N}$ & & 270 & 270 & 270 & 270 & 270 & 270 \\
\hline \multirow[t]{2}{*}{ EBIT } & Corr. Pearson & $0.933^{* *}$ & 1 & $0.864^{* *}$ & $0.849^{* *}$ & $0.729^{* *}$ & $0.827^{* *}$ & 0.234 \\
\hline & Sig. (2-tailed) & 0.000 & & 0.000 & 0.000 & 0.000 & 0.000 & 0.193 \\
\hline \multirow{4}{*}{$\Pi^{p^{\mathrm{T}}}$} & $\mathrm{N}$ & 270 & & 270 & 270 & 270 & 270 & 270 \\
\hline & Corr. Pearson & $0.685^{* *}$ & $0.864^{* *}$ & 1 & $0.542^{* *}$ & $0.476^{* *}$ & $0.708^{* *}$ & $0.834^{* *}$ \\
\hline & Sig. (2-tailed) & 0.000 & 0.000 & & 0.000 & 0.000 & 0.000 & 0.000 \\
\hline & $\mathrm{N}^{\circ}$ & 270 & 270 & & 270 & 270 & 270 & 270 \\
\hline \multirow[t]{3}{*}{$\mathrm{CF}$} & Corr. Pearson & $0.973^{* *}$ & $0.849^{* *}$ & $0.542^{* *}$ & 1 & $0.848^{* *}$ & $0.712^{* *}$ & 0.125 \\
\hline & Sig. (2-tailed) & 0.000 & 0.000 & 0.000 & & 0.000 & 0.000 & 0.470 \\
\hline & $\mathrm{N}$ & 270 & 270 & 270 & & 270 & 270 & 270 \\
\hline \multirow[t]{3}{*}{$\mathrm{OCF}$} & Corr. Pearson & $0.830^{* *}$ & $0.729^{* *}$ & $0.476^{* *}$ & $0.848^{* *}$ & 1 & $0.828^{* *}$ & $0.561^{* *}$ \\
\hline & Sig. (2-tailed) & 0.000 & 0.000 & 0.000 & 0.000 & & 0.000 & 0.000 \\
\hline & $\mathrm{N}^{\circ}$ & 270 & 270 & 270 & 270 & & 270 & 270 \\
\hline \multirow[t]{3}{*}{ UFCF } & Corr. Pearson & $0.759^{* *}$ & $0.827^{* *}$ & $0.708^{* *}$ & $0.712^{* *}$ & $0.828^{* *}$ & 1 & $0.855^{* *}$ \\
\hline & Sig. (2-tailed) & 0.000 & 0.000 & 0.000 & 0.000 & 0.000 & & 0.000 \\
\hline & $\mathrm{N}$ & 270 & 270 & 270 & 270 & 270 & & 270 \\
\hline \multirow{3}{*}{ FCFE } & Corr. Pearson & 0.250 & 0.234 & $0.834^{* *}$ & 0.125 & $0.561^{* *}$ & $0.855^{* *}$ & 1 \\
\hline & Sig. (2-tailed) & 0.165 & 0.193 & 0.000 & 0.470 & 0.000 & 0.000 & \\
\hline & $\mathrm{N}$ & 270 & 270 & 270 & 270 & 270 & 270 & \\
\hline
\end{tabular}

Source: Our processing of directly collected data; ${ }^{* *}$. The correlation is significant at the 0.01 level (two-tailed). ${ }^{*}$. The correlation is significant at the 0.05 level (two-tailed)

Table 5. Comparison of economic and financial margins with parametric approach for paired samples (t-Student) income and financial margins-parametric approach (Corr. Pearson)

\begin{tabular}{|c|c|c|c|c|}
\hline \multirow[b]{2}{*}{ Couples of value } & & \multicolumn{3}{|c|}{ Values and statistics } \\
\hline & & Mean & $\mathrm{T}$ & Sig. (2-tailed) \\
\hline Couple 1 & EBITDA-CF & 206,140 & 8,513 & $0.000^{* *}$ \\
\hline Couple 2 & EBITDA-OCF & 310,878 & 6,833 & $0.000 * *$ \\
\hline Couple 3 & EBITDA-UFCF & $1,275,732$ & 17,801 & $0.000 * *$ \\
\hline Couple 4 & EBIT-CF & $-311,114$ & $-8,245$ & $0.000 * *$ \\
\hline Couple 5 & EBIT-OCF & $-206,376$ & 5.107 & $0.000 * *$ \\
\hline Couple 6 & EBIT-UFCF & 185,052 & 4.090 & $0.000 * *$ \\
\hline Couple 7 & PROFIT-FCFE & 100,102 & 3.349 & $0.002 * *$ \\
\hline
\end{tabular}

Source: Our processing of directly collected data; ${ }^{* *}$. The correlation is significant at the 0.01 level (two-tailed). *. The correlation is significant at the 0.05 level (two-tailed) 
A nonparametric approach was also applied, given the non-normality of the margin distributions as expressed by applying the KSD statistic, just as the Wilcoxon statistic (Wilcoxon Matched-Pairs SignedRanks Test) for paired samples. The pairwise comparison with a nonparametric approach confirms that in all comparisons, we can reject the null hypothesis of equality between the means with the two-sided test's significance at $1.00 \%$ in six cases and significance at $5.00 \%$ in one case. The analysis shows that the tomato processing sector firms' economic and financial margins are different even if they are related. In fact, the firms in the considered sample have a relevant absorption of capital in the cycle of working capital, in particular due to the long inventory cycle and because of the high average delay in collecting commercial credits, particularly from large retail chains. Given these results, a manager that considers only economic data for the management of firms in the sector could make the wrong decisions. Moreover, even if characterized by positive profit, firms may not be able to pay dividends given that profit is statistically higher than FCFE. The analysis shows that profit margins (EBIT, EBITDA and PROFIT) are statistically different from financial margins $(\mathrm{CF}$, OCF, UFCF and FCFE). This difference is determined by the capital structure of the tomato processing firms.

\section{Discussion}

The research plan would therefore consider the determinants of economic (PROFIT) and cash flow (FCFE) margins available for equity holders, showing which variables are the determinants of these flows, in order to provide useful information for managing firms in the tomato processing sector. To achieve this goal, regression analysis aims to quantify the causal relationship between a variable to be explained (the dependent variable) and one or more explanatory variables (independent variables). First, we would quantify the relation between financial and economic flow; the research would analyze if there was a relation between a financial return on equity capital for a given period, $\mathrm{t}\left(\mathrm{FOE}_{\mathrm{t}}\right)$ and some independent variables. FOE expresses the amount of cash available for equity holders as expressed in the methodological part of the article. To achieve this aim, we consider the explanatory capacity of a linear regression model (first model). The model, as expressed in Equation 16, considers $\mathrm{FOE}_{t}$, which expresses the financial return available for equity holders, as an independent variable for a given time $(\mathrm{t})$. In the first regression models, the constant term is $\alpha$, TO is turnover (VP/invested capital), INV DAYS is the duration in days of the cycle of the inventories in stock, AR_DAYS is the duration in days of the average extension to customers, AP DAYS is the duration in days of the average extension from suppliers, DER is debt-to-equity ratio $(\mathrm{D} / \mathrm{E}), \mathrm{NFP} E$ is net financial position to equity ratio (NFP/E) and SIZE is the amount of capital invested in euro (total assets). The model then considers EBITDA, EBIT and PROFIT as explanatory variables, considered in values for the years $t$ and $t-1$ $\left(\right.$ EBITDA $_{t}$ and EBITDA $_{t-1}$, EBIT $_{t}$ and EBIT $_{t-1}$ and PROFIT $_{t}$ and PROFIT $_{t-1}$, respectively). At the same time, $\mathrm{CF}, \mathrm{OCF}$ and UFCF are considered explanatory variables and considered in their values for years $t$ and $t-$ 1 , giving then another six explanatory variables $\left(\mathrm{CF}_{\mathrm{t}}\right.$ and $\mathrm{CF}_{\mathrm{t}-1}, \mathrm{OCF}_{\mathrm{t}}$ and $\mathrm{OCF}_{\mathrm{t}-1}$ and $\mathrm{UFCF}_{\mathrm{t}}$ and $\mathrm{UFCF}_{\mathrm{t}-1}$, respectively). The model could be expressed as follows:

$$
\begin{aligned}
& \text { FOE }_{\mathrm{t}}=\alpha+\beta_{1} \mathrm{TO}+\beta_{2} \mathrm{INV} \_ \text {DAYS }+\beta_{3} \text { AR_DAYS }+ \\
& +\beta_{4} \mathrm{AP} \_ \text {DAYS }+\beta_{5} \mathrm{DER}+\beta_{6} \mathrm{NFP} \mathrm{E}+\beta_{7} \mathrm{SIZE}+ \\
& +\beta_{8} \mathrm{ROS}+\beta_{9} \mathrm{EBITDA}_{\mathrm{t}}+\beta_{10} \mathrm{EBIT}_{\mathrm{t}}+\beta_{11} \mathrm{PROFIT}_{\mathrm{t}}+ \\
& \beta_{12} \mathrm{EBITDA}_{\mathrm{t}-1}+\beta_{13} \mathrm{EBIT}_{\mathrm{t}-1}+\beta_{14} \mathrm{PROFIT}_{\mathrm{t}-1}+\beta_{15} \mathrm{CF}_{\mathrm{t}}+ \\
& +\beta_{16} \mathrm{OCF}_{\mathrm{t}}+\beta_{17} \mathrm{UFCF}_{\mathrm{t}}+\beta_{18} \mathrm{CF}_{\mathrm{t}-1}+\beta_{19} \mathrm{OCF}_{\mathrm{t}-1}+ \\
& +\beta_{20} \mathrm{UFCF}_{\mathrm{t}-1}+\varepsilon
\end{aligned}
$$

The idea underlying this first model is that it could be possible to explain actual FOE (at a given time, t) considering a set of explanatory variables that express capital intensity (TO, SIZE), working capital cycle duration (INV_DAYS, AR_DAYS, AP_DAYS), debt level (DER, NFP_E), operative profitability (ROS), actual income margins (EBIT, EBITDA and PROFIT) and their respective values considered at $\mathrm{t}-1\left(\mathrm{EBIT}_{\mathrm{t}-1}\right.$, EBITDA $_{t-1}$ and PROFIT ${ }_{t-1}$ ), even considering actual financial margins (CF, OCF and UFCF) and their respective values considered at $\mathrm{t}-1 \quad\left(\mathrm{CF}_{t}, \mathrm{OCF}_{\mathrm{t}}\right.$ and $\left.\mathrm{UFCF}_{t}\right)$. Unless otherwise specified, all the explanatory variables are taken at a certain time, $t$. The first regression model, as expressed in Equation 16, is analyzed in the research plan (Table 6) and assumes a significant statistical capacity to explain $\mathrm{FOE}_{\mathrm{t}}$ values; the $\mathrm{F}$ statistic has high significance $(\mathrm{F}=0.000) ; \mathrm{R}^{2}$ is 0.962 , while adjusted $R^{2}$ has a value of 0.960 , expressing the capacity of the model to explain a great part of the variability of $\mathrm{FOE}_{t}$; the statistic DW is 2.052; and the majority of the variables are significant. First, TO has a positive effect on FOE values, expressing that an increase in turnover (then a decrease in the capitalintensive structure of assets) has a positive effect on the FCFE value. The explanatory variables of FOE generation are, in particular, values expressing the duration of the Working Capital (WC) cycle. INV_DAYS and AR_DAYS have a negative sign, expressing that an increase in WC durations has a negative effect on the FOE result, due to a decrease in cash available. AP DAYS has a positive sign on FOE, expressing the opposite situation. DER has a positive sign on FOE given that an increase in debt could generate cash, while an increase in financial debt (NFP_E) has the opposite sign; in fact, an increase in NFP has an effect on increasing interest charges. 
Table 6. Extract of the multiple regression model that shows the impact on $\mathrm{FOE}_{\mathrm{t}}$ of independent variables-first model, Equation 16

\begin{tabular}{|c|c|c|c|c|c|}
\hline \multirow[b]{2}{*}{ Model } & \multicolumn{2}{|c|}{$\begin{array}{l}\text { Unstandardized } \\
\text { Coefficient }\end{array}$} & \multicolumn{3}{|c|}{$\begin{array}{l}\text { Standardized } \\
\text { coefficient }\end{array}$} \\
\hline & $\mathrm{B}$ & Std. error & Beta & $\mathrm{t}$ & Sig. \\
\hline (Constant) & -0.1156 & 0.033 & - & 6.702 & $0.000 * * *$ \\
\hline TO & 0.2110 & 0.053 & 0.125 & 6.551 & $0.000 * * *$ \\
\hline INV_DAYS & 379.892 & 176.619 &,- 057 & $-2,151$ & $0.032 *$ \\
\hline AR_DAYS & -530.206 & 323.351 &,- 027 & $-2,131$ &, $034 *$ \\
\hline AP_DAYS & 755.529 & 406.899 &, 043 & 2.031 & $0.045^{*}$ \\
\hline DER & -0.0135 & 0.100 & -0.190 & 2.851 & $0.006^{* *}$ \\
\hline NFP_E & 0.1900 & 0.023 & 0.405 & -7.012 & $0.000^{* * *}$ \\
\hline SIZE- & 0.0101 & 0.261 & 0.067 & 2.078 & $0.040^{*}$ \\
\hline ROS & 0.1464 & 0.068 & 0.755 & 11.100 & $0.000 * *$ \\
\hline EBITDA $_{t}$ & 0.1060 & 0.065 & 0.152 & 1.616 & 0.107 \\
\hline $\mathrm{EBIT}_{t}$ & 0.1180 & 0.021 & 0.139 & 2.321 & $0.028^{*}$ \\
\hline PROFIT $_{t}$ & 0.0961 & 0.018 & 0.122 & 4.699 & $0.000 * * *$ \\
\hline EBITDA $_{\mathrm{t}-1}$ & 0.0844 & 0.015 & 0.098 & 0.884 & 0.230 \\
\hline $\mathrm{EBIT}_{\mathrm{t}-1}$ & 0.1160 & 0.034 & 0.041 & 0.491 & 0.551 \\
\hline PROFIT $_{\mathrm{t}-1}$ & 0.1182 & 0.101 & 0.055 & 2.110 & $0.040^{*}$ \\
\hline $\mathrm{CF}_{\mathrm{t}}$ & 0.1710 & 0.060 & 0.780 & 1.120 & 0.190 \\
\hline $\mathrm{OCF}_{\mathrm{t}}$ & 0.1280 & 0.018 & 0.129 & 2.320 & $0.028^{*}$ \\
\hline $\mathrm{UFCF}_{\mathrm{t}}$ & 0.0958 & 0.019 & 0.121 & 4.698 & $0.000 * * *$ \\
\hline $\mathrm{CF}_{\mathrm{t}-1}$ & 0.0846 & 0.021 & 0.101 & 1.364 & 0.171 \\
\hline $\mathrm{OCF}_{\mathrm{t}-1}$ & 0.0440 & 0.032 & 0.051 & 1.821 & 0.070 \\
\hline $\mathrm{UFCF}_{\mathrm{t}-1}$ & 0.4740 & 0.179 & 0.591 & 2.315 & $0.029^{*}$ \\
\hline
\end{tabular}

Source: Our processing of directly collected data; first model, Equation 16. Dependent variable: $\mathrm{FOE}_{\mathrm{t}}$

***. The relation is significant at the 0.001 level (2-tailed). **. The relation is significant at the 0.01 level (2-tailed). *. The relation is significant at the 0.05 level (2-tailed)

Table 7. Extract of the multiple regression model that shows the impact on $\mathrm{ROE}_{\mathrm{t}}$ of independent variables-second model, Equation 17

\begin{tabular}{|c|c|c|c|c|c|}
\hline \multirow[b]{2}{*}{ Model } & \multicolumn{2}{|c|}{$\begin{array}{l}\text { Unstandardized } \\
\text { coefficient }\end{array}$} & \multicolumn{3}{|c|}{$\begin{array}{l}\text { Standardized } \\
\text { coefficient }\end{array}$} \\
\hline & B & Std. error & Beta & $\mathrm{t}$ & Sig. \\
\hline (Constant) & -0.0988 & 0.031 & - & 6.520 & $0.000 * * *$ \\
\hline TO & 0.1899 & 0.055 & 0.109 & 6.020 & $0.000 * * *$ \\
\hline INV_DAYS & 302.445 & 150.988 &, 060 & 2,381 & $0.018^{*}$ \\
\hline AR_DAYS & 125.532 & 121.022 & 027 & 4,089 &, $000 * *$ \\
\hline AP_DAYS & 520.189 & 350.121 &, 410 & 7.040 & 0.081 \\
\hline $\mathrm{DER} \overline{\mathrm{R}}$ & 0.0240 & 0.210 & 0.203 & 1.488 & 0.138 \\
\hline NFP_E & 0.2100 & 0.029 & 0.405 & 1.744 & 0.082 \\
\hline SIZE & 0.1980 & 0.311 & 0.067 & 3.506 & $0.001 * *$ \\
\hline ROS & 0.1523 & 0.071 & 0.805 & 11.560 & $0.000 * *$ \\
\hline EBITDA $_{t}$ & 0.1150 & 0.078 & 0.213 & 2.633 & $0.009 *$ \\
\hline $\mathrm{EBIT}_{\mathrm{t}}$ & 0.2145 & 0.089 & 0.250 & 3.560 & $0.001 * *$ \\
\hline EBITDA $_{\mathrm{t}-1}$ & 0.1023 & 0.002 & 0.018 & 0.989 & 0.323 \\
\hline $\mathrm{EBIT}_{\mathrm{t}-1}$ & 0.0650 & 0.099 & 0.050 & 2.067 & $0.040^{*}$ \\
\hline $\mathrm{CF}_{\mathrm{t}}$ & 0.1560 & 0.055 & 0.651 & 1.318 & 0.189 \\
\hline $\mathrm{OCF}_{\mathrm{t}}$ & 0.3556 & 0.041 & 0.135 & 0.989 & 0.323 \\
\hline $\mathrm{UFCF}_{\mathrm{t}}$ & 0.0958 & 0.019 & 0.121 & 4.698 & $0.000 * * *$ \\
\hline $\mathrm{FCFE}_{\mathrm{t}}$ & 0.1011 & 0.325 & 0.150 & 4.267 & $0.000 * * *$ \\
\hline $\mathrm{CF}_{\mathrm{t}-1}$ & 0.0855 & 0.019 & 0.009 & 0.068 & 0.946 \\
\hline $\mathrm{OCF}_{\mathrm{t}-1}$ & 0.0445 & 0.062 & 0.048 & 0.263 & 0.793 \\
\hline $\mathrm{UFCF}_{\mathrm{t}-1}$ & 0.0886 & 0.218 & 0.052 & 0.360 & 0.719 \\
\hline FCFE $_{t-1}$ & 0.1125 & 0.131 & 0.055 & 3.588 & $0.001 * *$ \\
\hline
\end{tabular}

Source: Our processing of directly collected data; first model, Equation 16. Dependent variable: $\mathrm{ROE}_{\mathrm{t}}$

***.The relation is significant at the 0.001 level (2-tailed). ${ }^{* *}$.The relation is significant at the 0.01 level (2-tailed). *.The relation is significant at the 0.05 level (2-tailed) 
Even ROS is particularly important in increasing the FOE value. Income and financial margins at a certain time, $t$, have an effect on FOE at the same time, $t$ (particularly PROFIT $_{t}$ and $U_{F C F}$ ). Income and financial margins at t-1 have a limited effect on FOE, with the exception of the PROFIT $_{t-1}$ and $\mathrm{UFCF}_{\mathrm{t}-1}$ margins even with a relation significant only at the 0.05 level (two-tailed).

We would consider a second regression model to analyze if there was a relation between economic return on equity capital for a given period, $t\left(\mathrm{ROE}_{t}\right)$ and a set of independent variables as considered in the first regression model. ROE expresses the amount of PROFIT available for equity holders as expressed in the methodological part of the article. It then proposes an explanatory linear regression model (second model). In the second regression model, the constant term is $\alpha$, TO is turnover (VP/invested capital), INV_DAYS is the duration in days of the cycle of the inventories in stock, AR_DAYS is the duration in days of the average extension to customers, AP_DAYS is the duration in days of the average extension from suppliers, DER is debt-to-equity ratio (D/E), NFP_E is Net Financial Position to Equity ratio (NFP/E) and SIZE is the amount of the capital invested in euro (total assets). The model then considers EBITDA and EBIT as explanatory variables, considered in values for the years $t$ and $t-1$ $\left(\right.$ EBITDA $_{t}$ and EBITDA EB-1 $_{t}$, EBIT $\left._{t}\right)$. Obviously, PROFIT is not considered as an explanatory variable. At the same time, CF, OCF, UFCF and FCFE are considered explanatory variables and considered in their values for years $\mathrm{t}$ and $\mathrm{t}-1$, giving then another eight explanatory variables $\left(\mathrm{CF}_{\mathrm{t}}\right.$ and $\mathrm{CF}_{\mathrm{t}-1}, \mathrm{OCF}_{\mathrm{t}}$ and $\mathrm{OCF}_{\mathrm{t}-1}, \mathrm{UFCF}_{\mathrm{t}}$ and $\mathrm{UFCF}_{\mathrm{t}-1}$ and $\mathrm{FCFE}_{\mathrm{t}}$ and $\mathrm{FCEF}_{\mathrm{t}-1}$, respectively). The set of explanatory variables is the same as those considered in Equation 17, with the exception of FCFE instead of PROFIT. We express the second model as follows:

$$
\begin{aligned}
& \text { ROE }_{\mathrm{t}}=\alpha+\beta_{1} \mathrm{TO}+\beta_{2} \mathrm{INV} \_ \text {DAYS }+\beta_{3} \text { AR_DAYS }+ \\
& +\beta_{4} \mathrm{AP} \_\mathrm{DAYS}+\beta_{5} \mathrm{DER}+\beta_{6} \mathrm{NFP} \_\mathrm{E}+\beta_{7} \mathrm{SIZE}+ \\
& +\beta_{8} \mathrm{ROS}+\beta_{9} \mathrm{EBITD}_{\mathrm{t}}+\beta_{10} \mathrm{EBIT}_{\mathrm{t}}+\beta_{11} \mathrm{EBITDA}_{\mathrm{t}-1}+ \\
& +\beta_{12} \mathrm{EBIT}_{\mathrm{t}-1}+\beta_{13} \mathrm{CF}_{\mathrm{t}}++\beta_{14} \mathrm{OCF}_{\mathrm{t}}+\beta_{15} \mathrm{UFCF}_{\mathrm{t}}+ \\
& +\beta_{16} \mathrm{FCFE}_{\mathrm{t}}+\beta_{17} \mathrm{CF}_{\mathrm{t}-1}++\beta_{18} \mathrm{OCF}_{\mathrm{t}-1}+\beta_{19} \mathrm{UFCF}_{\mathrm{t}-1}+ \\
& +\beta_{19} \mathrm{FCFE}_{\mathrm{t}-1}+\varepsilon
\end{aligned}
$$

The second regression model as expressed in Equation 17 is analyzed in Table 7 and assumes a significant statistical capacity to explain $\mathrm{FOE}_{\mathrm{t}}$ values; the $\mathrm{F}$ statistic has high significance $(\mathrm{F}=0.000) ; \mathrm{R}^{2}$ is 0.895 , while adjusted $\mathrm{R}^{2}$ has a value of 0.889 , expressing the capacity of the model to explain a great part of the variability of $\mathrm{ROE}_{t}$; the statistic $\mathrm{DW}$ is 2.121 ; and the majority of the variables are significant. First, TO has a positive effect on ROE values (as in SIZE), expressing that an increase in turnover has a positive effect on the
PROFIT value. ROE generation is even affected by values expressing the duration of the Working Capital (WC) cycle. INV_DAYS and AR_DAYS have a positive sign, expressing that an increase in WC durations has a positive effect on the ROE result, even if this causes a decrease in cash available. AP_DAYS is not statistically significant as DER and NFP E even are. Obviously, ROS is particularly important in increasing the ROE value, just as EBIT and EBITDA are at a certain time, $t$. It is, then, interesting to note that income and financial margins at a certain time, $t$, have an effect on ROE (particularly EBITDA $t$ and EBIT $_{t}$ and even $\mathrm{UFCF}_{t}$ and $\mathrm{FCFE}_{\mathrm{t}}$ ), while in the first model, income and financial margins at $\mathrm{t}-1$ have a limited effect on ROE, with the exception of EBIT $_{t-1}$ and FCFE $_{t-1}$.

\section{Conclusion}

The analysis of firms' samples in the sector of tomato processing shows that these firms have characteristics of production and investment that affect capital structure. Tomato processing firms require large amounts of capital to finance investments in fixed assets (buildings, plants and equipment for tomato processing) and working capital (particularly inventories, including finished goods and accounts receivable). Because of the absorption of capital due to the investment and working capital cycles and even considering the high level of financial debt, it is necessary to assess the sustainability of the business cycle.

For this purpose, considering a sample of 54 firms over a five-year period (270 observations), the article calculates profit margins (EBITDA, EBIT and PROFIT) and financial margins (CF, OCF, UFCF and FCFE); the analysis highlights relevant correlations between economic and financial margins, even if it is possible to note statistically significant differences. It thus appears that profit margins are not adequate to approximate financial margins in business valuations as it often happens in bank analyses and also in the analyses carried out by firms' management. In fact, 38 of the 54 companies considered in the sample do not prepare financial statements and 48 do not do financial planning with a forecast horizon of more than three months. The analysis also shows that tomato processing firms often have difficulty paying interest charges and distributing dividends, even in the presence of positive profit, as expressed by UFCF and FCFE values, respectively. The analyzed data show that there is difficulty in the sustainability of the financial management cycle for the firms sampled, particularly in the payment of the cost of debt. The analysis of FOE and ROE, as expressed by regression models, may help firm's owner to properly assess the sustainability of the management cycle and even for credit institutions that could assess with greater accuracy the creditworthiness of companies (even considering subsidiary guarantees issued by credit 
unions to improve the sustainability of the business cycle). At the same time, the method could be applied by policy makers, operating with direct (loans) or indirect (mutual guarantees) aid policies in favor of the tomato sector. In fact, an increased capacity to evaluate the sustainability of the cycle of a firm that has received public funds is useful to reduce the risk of inefficient uses of collective resources.

\section{Acknowledgement}

The authors would thanks analisiaziendale. It for IT assistance, particularly in data base management.

\section{Funding Information}

The authors did not receive any private or public funding to develop the research.

\section{Author's Contributions}

This study is a result of the full collaboration of all the authors.

Mattia Iotti: Wrote paragraphs Material and Methods, Discussion.

Giuseppe Bonazzi: Wrote paragraphs Introduction, Results and Conclusion.

\section{Ethics}

The authors have no conflicts of interest in the development and publication of current research.

\section{References}

Barnes, P., 1987. The analysis and use of financial ratios: A review article. J. Bus. Finance Account., 14: 449-461.

DOI: $10.1111 / \mathrm{j} .1468-5957.1987 . t b 00106 . \mathrm{x}$

Battilani, A., 2007. Processing tomato cropping system sustainability pathways: State of the art and rules of thumb. Acta Hor., 758: 207-218.

Beaver, W.H., 1966. Financial ratios as predictors of failure. J. Account Res., 471-111.

Bodenhorn, D., 1964. A cash-flow concept of profit. J. Finance, 19: 16-31. DOI: $10.1111 /$ j.1540-6261.1964.tb00742.x

Bonazzi, G. and M. Iotti, 2014a. Agricultural cooperative firms: Budgetary adjustments and analysis of credit access applying scoring systems. Am. J. Applied Sci., 11: 1181-1192. DOI: 10.3844/ajassp.2014.1181.1192

Bonazzi, G. and M. Iotti, 2014b. Interest Coverage Ratios (ICRs) and financial sustainability: Application to firms with bovine dairy livestock. Am. J. Agric. Biological Sci., 9: 482-489.

DOI: 10.3844 ajabssp.2014.482.489
Bowen, R.M. and O. Owen, 1986. Evidence on the relationships between earnings and various measures of cash flow. Accoun. Rev., 4: 713-725.

Charitou, A. and G. Panagiotides, 1999. Financial analysis, future earnings and cash flows and the prediction of stocks returns: Evidence for the UK. Accoun. Bus. Res., 29: 281-298.

DOI: 10.1080/00014788.1999.9729589

Cleary, S., 1999. The relationship between firm investment and financial status. J. Finance, 4: 673-692.

DOI: $10.1111 / 0022-1082.00121$

De Miguel, A. and J. Pindado, 2001. Determinants of capital structure: New evidence from Spanish panel data. J. Corporate Finance, 7: 77-99. DOI: $10.1016 / \mathrm{S} 0929-1199(00) 00020-1$

Dechow, P.M. and I.D. Dichev, 2002. The quality of accruals and earnings: The role of accrual estimation errors. Account. Rev., 77: 35-59. DOI: $10.2308 /$ accr.2002.77.s-1.35

Dechow, P.M., 1994. Accounting earnings and cash flows as measures of firm performance: The role of accounting accruals. J. Accoun. Econ., 18: 3-42. DOI: 10.1016/0165-4101(94)90016-7

Di Trapani, A.M., R. Squatrito, M. FoderÃ, R. Testa and S. Tudisca et al., 2014. Payment for environmental services for the sustainable development of the territory. Am. J. Environ. Sci., 10: 480-488. DOI: 10.3844/ajessp.2014.480.488

Dothan, M., 2006. Costs of financial distress and interest coverage ratios. J. Financ. Res., 29: 147-162. DOI: $10.1111 / \mathrm{j} .1475-6803.2006 .00171 . \mathrm{x}$

Dunn, P. and L. Cheatham, 1999. Fundamentals of small business financial management for start-up, survival, growth and changing economic circumstances. Managerial Finance, 19: 1-13. DOI: $10.1108 / \mathrm{eb} 013737$

Engindeniz, S., 2007. Economic analysis of processing tomato growing: The case study of Torbali, West Turkey. Spanish J. Agric. Res., 5: 7-15. DOI: $10.5424 / \mathrm{sjar} / 2007051-218$

Fazzari, S. and B. Petersen, 1993. Working capital and fixed investment: New evidence on financing constraints. Rand J. Econo., 24: 328-342.

Finger, C.A., 1994. The ability of earnings to predict future operating cash flows has been increasing-not decreasing. J. Account. Res., 32: 210-223. DOI: $10.1111 / \mathrm{j} .1475-679 X .2005 .00189 . \mathrm{X}$

Glancey, K., 1998. Determinants of growth and profitability in small entrepreneurial firms. Int. J. Entrepreneurial Behav. Res., 4: 18-27. DOI: $10.1108 / 13552559810203948$

Gombola, M.J., M.E. Haskin, J.E. Ketz and D.D. Williams, 1987. Cash flow in bankruptcy prediction. Financ. Manage., 16: 55-65.

Grablowsky, B.J., 1984. Financial management of inventory. J. Small Bus. Manage. 
Gray, S., A. Mirkovic and V. Ragunathan, 2006. The determinants of credit ratings: Australian evidence. Aus. J. Manage., 31: 333-354. DOI: $10.1177 / 031289620603100208$

Greenberg, R.R., G.L. Johnson and K. Ramesh, 1986. Earnings versus cash flow as a predictor of future cash flow measures. J. Account., 1: 266-277. DOI: $10.1177 / 0148558 \times 8600100402$

Howorth, C. and P. Westhead, 2003. The focus of working capital management in UK small firms. Manage. Account. Res., 14: 94-111. DOI: $10.1016 / \mathrm{S} 1044-5005(03) 00022-2$

Hussain, S. and A. Al-Attar, 2004. Corporate data and future cash flows. J. Bus. Finance Account., 31: 861-903. DOI: 10.1111/j.0306-686X.2004.00560.x

Iotti, M. and G. Bonazzi, 2014. Tomato processing firms' management: A comparative application of economic and financial analyses. Am. J. Applied Sci., 11: 1135-1151.

DOI: 10.3844/ajassp.2014.1135.1151

Keskin, G. F. F. Tatlidil and I. Dellal, 2010. An analysis of tomato production cost and labor force productivity in Turkey. Bulg. J. Agric. Sci., 16: 692-699.

Kieschnick, R., M. La Plante and R. Mousawwi, 2008. Working Capital management, corporate governance and firm value. University of North Texas University Press, Austin.

Kwon, Y.K., 1989. Accrual versus cash-basis accounting method: An agency-theoretic comparison. J. Accoun. Public Policy, 8: 267-281. DOI: 10.1016/0278-4254(89)90015-X

Lagerkvist, C.J. and H. Andersson, 1996. Taxes, inflation and financing, the rate of return to capital for the agricultural firm. Eur. Rev. Agric. Econ., 23: 437-454. DOI: 10.1093/erae/23.4.437

Lorek, K.S. and G.L. Willinger, 1996. A multivariate time-series prediction model for cash-flow data. Account. Rev., 71: 81-102.
Molina, C.A. and L.A. Preve, 2009. Trade receivables policy of distressed firms and its effect on the costs of financial distress. Financ. Manage., 38: 663-686. DOI: 10.1111/j.1755-053X.2009.01051.X

Moro Visconti, R., 1999. Il cash flow return on investment $\mathrm{CF}$ ROI. Impresa Commerciale Industriale, 21: 34-51.

Ohlson, J., 1980. Financial ratios and the probabilistic prediction of bankruptcy. J. Accoun. Res., 4: 109-131.

Padachi, K., 2006. Trends in working capital management and its impact on firms' performance: An analysis of Mauritian small manufacturing firms. Int. Rev. Bus. Res., 2: 45-58.

Peel, M.J. and N. Wilson, 1996. Working capital and financial management practices in the small firm sector. Int. Small Bus. J., 14: 52-68. DOI: $10.1177 / 0266242696142004$

Rayburn, J., 1986. The association of operating cash flow and accruals with security returns. J. Account. Res., 24: 112-133.

Russel, P.B., 2009. The cash flow implications of managing working capital and capital investment. J. Bus. Econ. Stud., 15: 98-108.

Sgroi, F., A.M. Di Trapani, R. Testa and S. Tudisca, 2014a. Strategy to increase the farm competitiveness. Am. J. Agric. Biol. Sci., 9: 394-400. DOI: 10.3844/ajabssp.2014.394.400

Sgroi, F., A.M. Di Trapani, R. Testa and S. Tudisca, 2014b. Economic sustainability of early potato production in the mediterranean area. Am. J. Applied Sci., 11: 1598-1603. DOI: 10.3844 /ajassp.2014.1598.1603

Taylor, D., 2011. Optimizing Working Capital. 1st Edn., Business Credit, VI.

Wang, Z. and J. Eichenseher, 1998. Informativeness and predictability of cash flows. J. Applied Bus. Res., 14: 21-32.

Wilson, G.P., 1987. The incremental information content of accrual and funds components of earnings after controlling for earnings. Account. Rev. 